\title{
Long-term results of photorefractive keratectomy for myopia and myopic astigmatism
}

\author{
Resultados a longo prazo de ceratectomia fotorefrativa para \\ miopia e astigmatismo miópico
}

\author{
Ester Sakae Yamazaki ${ }^{1}$ \\ Iane Stillitano ${ }^{2}$ \\ Anelise Dutra Wallau ${ }^{3}$ \\ Juliana Mantovani Bottós ${ }^{4}$ \\ Mauro Campos 5
}

From the Refractive Surgery Sector /Instituto da Visão, Universidade Federal de São Paulo - UNIFESP - São Paulo (SP) Brazil.

Pós-graduanda, nível doutorado, do Departamento de Oftalmologia da Universidade Federal de São Paulo UNIFESP - São Paulo (SP) - Brasil.

${ }^{2}$ Pós-graduanda, nível doutorado, do Departamento de Oftalmologia - UNIFESP - São Paulo (SP) - Brasil.

${ }^{3}$ Pós-graduanda, nível doutorado, do Departamento de Oftalmologia - UNIFESP - São Paulo (SP) - Brasil.

${ }^{4}$ Residente do Departamento de Oftalmologia - UNIFESP - São Paulo (SP) - Brasil.

${ }^{5}$ Professor Livre Docente e Chefe do Setor de Cirurgia Refrativa do Departamento de Oftalmologia - UNIFESP - São Paulo (SP) - Brasil.

Correspondence author: Ester Sakae Yamazaki. Rua Borges Lagoa, 368 - São Paulo (SP) CEP 04038-000 E-mail: ester.yamazaki@gmail.com

Recebido para publicação em 22.10.2006

Última versão recebida em 18.07.2007

Aprovação em 12.09.2007

\begin{tabular}{l} 
ABSTRACT \\
\hline Purpose: To assess the long-term refractive outcomes of photo- \\
refractive keratectomy in myopia and myopic astigmatism. Methods: \\
A retrospective study of 120 photorefractive keratectomy operated \\
eyes with at least four-year follow-up (maximum of 96 months, mean \\
follow-up 55 months). We divided patients into group 1 (G1) spherical \\
equivalent (SE) up to -4.00 diopters (D) and group 2 (G2) SE $>-4.00$ \\
D. The Summit Apex Plus ${ }^{\circledR}$ excimer laser was used for ablation. All \\
eyes were analyzed in terms of uncorrected and best spectacle \\
corrected visual acuity (UCVA/BSCVA) and cycloplegic refraction. \\
Data were analyzed using the Refractive Surgery Consultant Elite \\
database software. Results: G1 with 85 eyes (49 patients) presented \\
mean SE - 2.42 D and G2 with 35 eyes (22 patients) and mean SE of \\
-4.45 D. Ninety-four percent of eyes in G1 and $82.9 \%$ of G2 were \\
within \pm 1.00 D of emmetropia at 4 years. The UCVA was $20 / 30$ or \\
better in $82.0 \%$ of G1 eyes and $77.0 \%$ of G2 in the last postoperative \\
follow-up. No patient lost more than one line in G2 compared to \\
$13.0 \%$ in G1. Eyes that gained one or more lines after 4 -year follow- \\
up were $11.9 \%$ G1 and $2.9 \%$ in G2, respectively. A statistically \\
significant positive correlation was found between achieved versus \\
attempted refractive correction in both groups (r=0.925, p $<0.0005$ ). \\
Conclusion: Photorefractive keratectomy was a safe and stable surgical \\
procedure to correct myopic refractive errors, with no significant \\
change in mean postoperative spherical equivalent refraction in the \\
long-term follow-up.
\end{tabular}

Keywords: Keratectomy, photorefractive, excimer laser; Myopia/surgery; Astigmatism/surgery; Treatment outcome; Visual acuity

\section{INTRODUCTION}

Excimer laser photorefractive keratectomy (PRK) has been widely used for myopic corrections in the last decades ${ }^{(1)}$.

Since the approval of PRK for myopia up to -7.00D, in 1996, by the US Food and Drug Administration, interest on excimer laser surgery and the need for long-term follow-up has increased.

Several well-designed studies report the results of $\mathrm{PRK}^{(1-6)}$ but few describe long-term outcomes ${ }^{(5-6)}$, which is of particular importance to assess refractive stability, efficacy and potential late-phase complications. For best results, it is necessary to understand each aspect of postoperative changes. 
Recently, PRK is gaining new interest in custom ablations due to some advantages when compared to laser in situ keratomileusis (LASIK). In addition, PRK may provide better outcome following wavefront-guided ablation in certain cases, such as thin corneas, large pupils or patients at increased risk for ocular trauma, than when such treatment is buried under a LASIK flap ${ }^{(2)}$.

This retrospective study was conducted to assess the longitudinal results of PRK surgery, including visual acuity, refraction and vector analysis, in two groups of patients who completed at least four-year follow-up and underwent myopic and compound myopic astigmatism correction.

\section{METHODS}

A retrospective non-randomized study of 120 eyes (71 patients) who completed at least four-year follow-up was performed from September 1994 to January 1998, at the Vision Institute, Refractive Surgery Sector, Universidade Federal de São Paulo (UNIFESP). The study was approved by the Research Ethics Committee of the UNIFESP. The informed consent was obtained from all patients after through explanation of the procedure and its potential benefits and risks.

Mean age was $29 \pm 7.7$ years (20 to 53 years). Females accounted for $60.0 \%$ (72 patients) and males for $40.0 \%$ (48 patients). All completed at least 4-year follow up and the longest lasted 8 years; in that, $49 \%$ completed 4 to 5 years, $26.7 \% 5$ to 6 years, $17.5 \% 6$ to 7 years and $6.6 \% 7$ to 8 years. Mean follow up was 55 months.

Patients were divided into 2 groups: group 1; spherical equivalent (SE) up to -4.00 diopters (D), $(n=85$ eyes, mean $\mathrm{SE}$ $-2.42 \pm 0.86 \mathrm{D})$ and group 2 ; $\mathrm{SE}>-4.00 \mathrm{D}(\mathrm{n}=35$ eyes, mean $\mathrm{SE}$ $-4.45 \mathrm{D})$.

The inclusion criteria were absence of ocular pathology, no previous ocular surgery, refractive astigmatism less than $1.50 \mathrm{D}$, refractive stability and at least four-year follow-up.

The Summit Apex Plus ${ }^{\circledR}$ excimer laser was used to perform the following ablation profiles: PRK spheric ablation, PARK (toric ablation) and PRK multizone ablation with standard laser parameters including an energy fluence of $180 \mathrm{Mj} / \mathrm{cm}^{2}$ and a repetition rate of $10 \mathrm{~Hz}$.

The PRK procedure was performed under topical anesthesia, with the patient fixating a target light within the delivery system. A 7.0-mm optical zone centered over the central pupil was marked. The corneal epithelium was removed manually with a blunt PRK spatula within 7.0-mm optical zone mark and the treatment zone was between 4.5 and $6.0 \mathrm{~mm}$.

In cases of photoastigmatic (PARK) ablation profile, photoablation was delivered through a polymethyl methacrylate erodible astigmatic mask inserted within the laser optical pathway oriented according to the attempted astigmatic correction.

In multizone ablation profile, tree zones between 4.5 and $6.0 \mathrm{~mm}$ were chosen based on the refractive correction and corneal thickness. Fifty percent of the full correction was made in the smallest zone; the remaining $50 \%$ of the correction and astigmatism was blended into the 2 other zones.

After surgery, a bandage contact lens was placed on the eye until the epithelium was healed. A topical antibiotic was administered four times a day for one week and corticosteroid regimen was prescribed four times a day for one month.

All eyes were analyzed in terms of uncorrected and best corrected visual acuity (UCVA/BSCVA) and cycloplegic refraction.

Pre and postoperative data, linear regression and astigmatism vector analysis were calculated using the Refractive Surgery Consultant Elite database software ${ }^{\circledR}$.

Vector analysis was used to represent a surgically induced refractive change (SIRC) by doubled angle plots that provide a useful means to visually evaluate cylinder outcomes. They are created for determining cylinder values to avoid having axis shifts misrepresent astigmatic changes.

Linear regression was used for evaluation of the relationship between intended and achieved correction by Pearson's correlation coefficient(R) and regression coefficient (b) with a confidence interval of 1.0

\section{RESULTS}

\section{Efficacy}

The mean postoperative note in UCVA was 20/20 or better in $46.4 \%$ and $20 / 30$ or better in $82.0 \%$ of group 1 and $20 / 20$ or better in $34.7 \%$ and $20 / 30$ or better in $77.0 \%$ of group 2 at 4 years follow-up (Figure 1).

\section{Safety}

The BSCVA presented no change $(<1$ line $)$ in $75 \%$ in group 1 and $97.1 \%$ in group 2 . None of the patients lost more than one line in group 1 compared to $13 \%$ in group 2 .

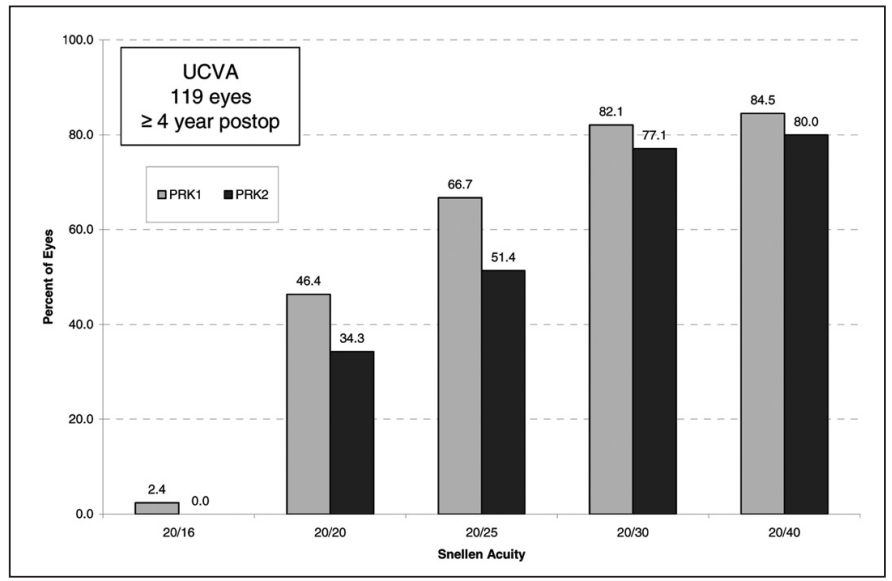

Figure 1- Postoperative uncorrected visual acuity in an over 4-year follow-up 
$11.9 \%$ of eyes in group 1 and $2.9 \%$ in group 2 gained one or more lines after 4 years of follow- up (Figure 2).

\section{Stability}

Mean postoperative SE over time is shown in figure 3.

In group 1, a long with all the follow-ups, the mean SE was closer to emmetropia and in group 2 , there was a hyperopic shift between 1 and 3 months and by 1 -year, the mean SE was very close to emmetropia.

Refraction appeared to stabilize up to 1-year, however, between 12 months and 48 months a slight regression was observed. The final mean SE was $-0.17 \pm 0.60 \mathrm{D}$ (group 1) and $-0.65 \pm 1.04 \mathrm{D}$ (Group 2).

\section{Predictability}

The comparison between the two groups for the postoperative showed a SE refraction of $+/-0.50 \mathrm{D}$, was respectively for groups 1 and 2 as follows: $64.7 \%$ and $57.1 \%$ in the first month, $55.3 \%$ and $54.3 \%$ within 3 months, $67.9 \%$ and $54.3 \%$ at one year and $67.9 \%$ and $54.3 \%$ at the last postoperative data (Table 1).

A statistically significant positive correlation $(p<0.005)$ was found between achieved versus attempted refractive correction in both groups according to postoperative 1 month, 3 months, 1year, $\geq 4$ years: group $1(\mathrm{r}=0.881, \mathrm{r}=0.947, \mathrm{r}=0.944, \mathrm{r}=0.925)$ and group $2(\mathrm{r}=0.957, \mathrm{r}=0.964, \mathrm{r}=0.918, \mathrm{r}=0.925)$.

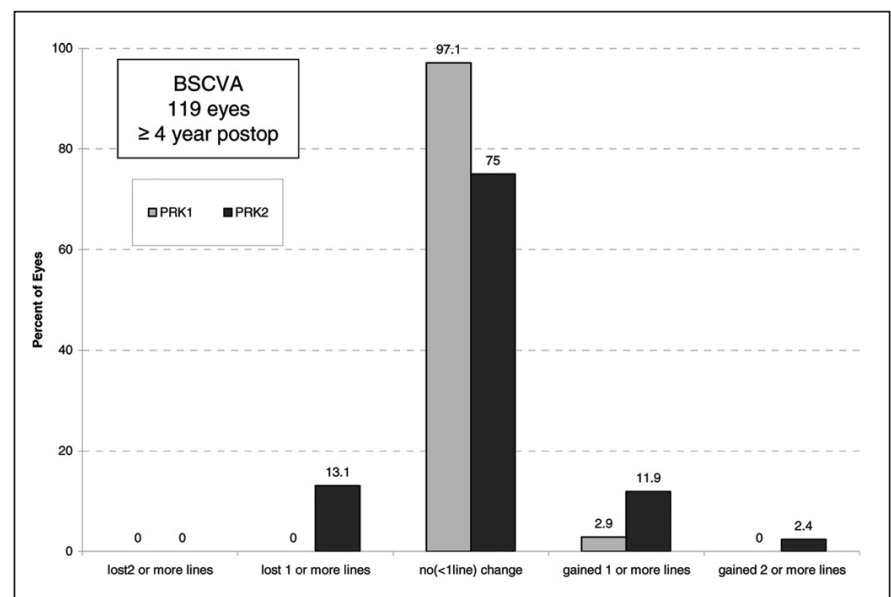

Figure 2 - Postoperative best corrected visual acuity in an over 4-year follow-up
The scattergram (Figure 4) reported by the Refractive Surgery Consultant Elite database software ${ }^{\circledR}$, show us, at the first postoperative month, group 1, the amount of correction that was achieved (regression formula was $Y=0.99 X$, with a significant $\mathrm{p}<0.0005$ and $\mathrm{r}=0.881$ ). On the other hand at the same follow-up period, a hypercorrection was observed in G2 with $\mathrm{SE}>-4.0 \mathrm{D}$; mean attempted correction was $-4,45 \mathrm{D}$ and $5.23 \mathrm{D}$ was achieved $(\mathrm{Y}=1.15 \mathrm{X}, \mathrm{p}<0.0005, \mathrm{r}=0.957)$. Both groups presented slightly undercorrection in absolute cylinder at this period. At 3 months and one year of follow-up the scattergram values for both groups were very close to what had been planned $(\mathrm{p}<0.0005)$. In the last postoperative analysis (at least 4 years), G1 mean attempted correction was $-2.44 \mathrm{D}$ and $-2.34 \mathrm{D}$ was achieved $(\mathrm{Y}=0.94 \mathrm{X}, \mathrm{p}<0.0005, \mathrm{r}=0.925)$ and $\mathrm{G} 2$ mean attempted was $-4.45 \mathrm{D}$ and $-3.82 \mathrm{D}$ was achieved $(\mathrm{Y}=0.85 \mathrm{X}$, $\mathrm{p}<0.0005, \mathrm{r}=0.925)$. Both groups showed a small amount of under correction at this last follow-up.

A statistically significant positive correlation was found between achieved versus attempted refractive correction in both groups $(\mathrm{r}=0.925, \mathrm{p}<0.0005)$.

The mean surgical induced refractive change (SIRC) value for group 1 was $0.58 \pm 0.60 \mathrm{D}$ ( 1 year postop) and $0.61 \pm$ $0.47 \mathrm{D}$ (e $\leq 4$ years postop). The mean SIRC value for group 2 was $0.76 \pm 0.56 \mathrm{D}$ ( 1 year postop) and $0.64 \pm 0.42 \mathrm{D}$ (e $\leq 4$ years postop). Double angle plots at e $\geq 4$ years can be observed for group 1 and 2, respectively, in figure 5 .

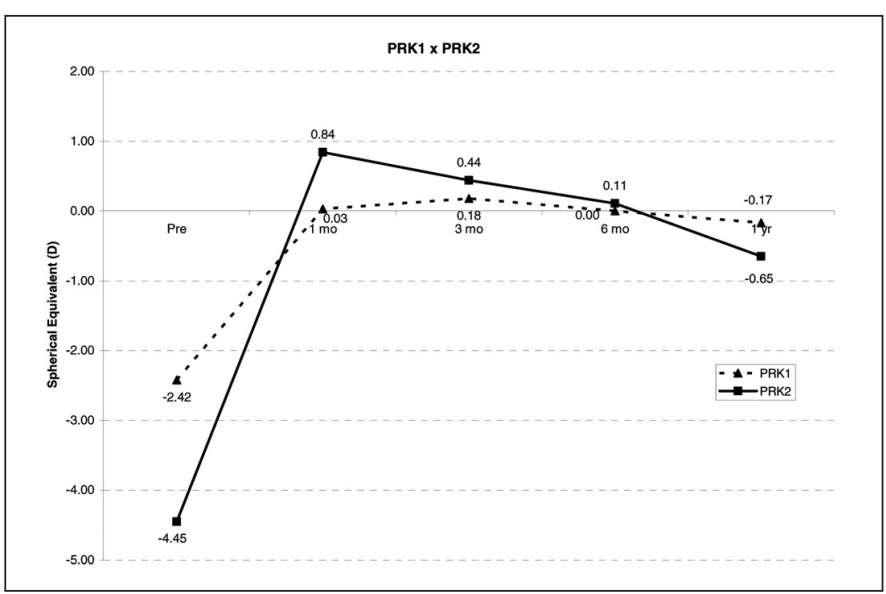

Figure 3 - Mean spherical equivalent in both groups over time

\begin{tabular}{|c|c|c|c|c|c|c|c|c|}
\hline \multirow[t]{2}{*}{ SE (D) } & \multicolumn{2}{|c|}{1 month $\mathrm{N}(\%)$} & \multicolumn{2}{|c|}{3 months $\mathrm{N}(\%)$} & \multicolumn{2}{|c|}{1 year $N(\%)$} & \multicolumn{2}{|c|}{$\geq 4$ years $N(\%)$} \\
\hline & PRK1 & PRK2 & PRK1 & PRK2 & PRK1 & PRK2 & PRK1 & PRK2 \\
\hline$+/-0.5$ & $55(64.7)$ & $20(57.1)$ & 47 (55.3) & 19 (54.3) & 57 (67.9) & 19 (54.3) & 57 (67.9) & $19(54.3)$ \\
\hline$<-1.0$ & $6(7.1)$ & 0 & $2(2.4)$ & 0 & $2(2.4)$ & $4(11.4)$ & $4(4.8)$ & $6(17.1)$ \\
\hline$>+1.0$ & $7(8.2)$ & $11(31.4)$ & $4(4.7)$ & $5(14.3)$ & $2(2.4)$ & $6(17.1)$ & $1(1.2)$ & 0 \\
\hline
\end{tabular}




\section{DISCUSSION}

Long-term follow-up is essential in refractive surgery for evaluation of stability and efficacy. The main goal of our study was to evaluate long-term refractive outcomes of patients submitted to PRK.

The results of this study show that the procedure was safe, effective and moreover, stable.

Previous studies have commented on the safety and efficacy of using the excimer laser photorefractive keratectomy for the correction of myopic astigmatism (Table 2). Uncorrected visual acuity of 20/40 or better was reported in 55\% to $93 \%$ of the eyes ${ }^{(1-2)}$ and $88.5 \%$ in another study ${ }^{(3)}$. Visual acuity of $20 / 25$ or better was achieved in $62.4 \%$ of myopic eyes up to $-6.50 \mathrm{D}^{(4)}$.

Our experience with the Summit Apex Plus excimer laser in the correction of compound myopic astigmatism compares favorably with these results.

Some authors have reported in a PRK 6-year follow-up study that induced refractive change for mild-to-moderate myopia stabilizes between 3 and 6 months and remains stable for up to 6 years $^{(5)}$.

Our study showed that $67.9 \%$ (Group 1) and 54.3\% (Group 2) were within $\pm 0.5 \mathrm{D}$ of emmetropia. These values are consistent with the FDA requirements for predictability that require 50\% within $\pm 0.5 \mathrm{D}$ of emmetropia.

A consistent trend toward under correction is observed in the analysis of 12 months after PARK, of both compound myopia and astigmatism ${ }^{(7)}$.

In the presenting study we also observed similar corre- lation between achieved and attempted correction in both groups. The achieved correction underestimated attempted correction in the first month up to the last follow-up period. Four years follow-up of multizone PRK for myopia of $-6,00$ to $-10,00 \mathrm{D}$ showed visual acuity of $20 / 40$ in $79.2 \%{ }^{(7)}$.

When PRK was performed in myopias up to $-6.00 \mathrm{D}$ the results improved to $97 \%$ of $20 / 40^{(8)}$.

According to one of the largest PARK prospective stu$\operatorname{dies}^{(9)}, 6097$ eyes were assessed 12 months postoperatively and compared with those in 3004 eyes that had spherical PRK, in a total of 9101 eyes. They report that excimer laser PARK was an effective treatment for compound myopic astigmatism, but predictability decreased and complications increased as the attempted astigmatic correction increased.

One of the longest prospective studies has shown that refractive stability was maintained for up to 12 years in the treatment of mild to moderate myopia. There was no evidence of progressive time-dependent hyperopic shift, late regression or late-onset corneal haze after $\mathrm{PRK}^{(10)}$.

After 5 and 8 years of follow-up for moderate myopia, two studies have reported the same postoperative spherical equivalent of $\pm 1,00 \mathrm{D}^{(11-12)}$. We demonstrated general stability of $<0.50 \mathrm{D}$ in the spherical equivalent up to 48 months, however, a slightly refractive late regression in both groups was observed between 1 year and at least 4-year follow-up.

Like any surgical technique, PRK has presented advantages and some disadvantages. Some advantages of PRK when compared to LASIK are the risk associated with the intraoperative and postoperative flap-related complications in LASIK. The short-term problems associated with PRK were

\section{SCATTERGRAM}

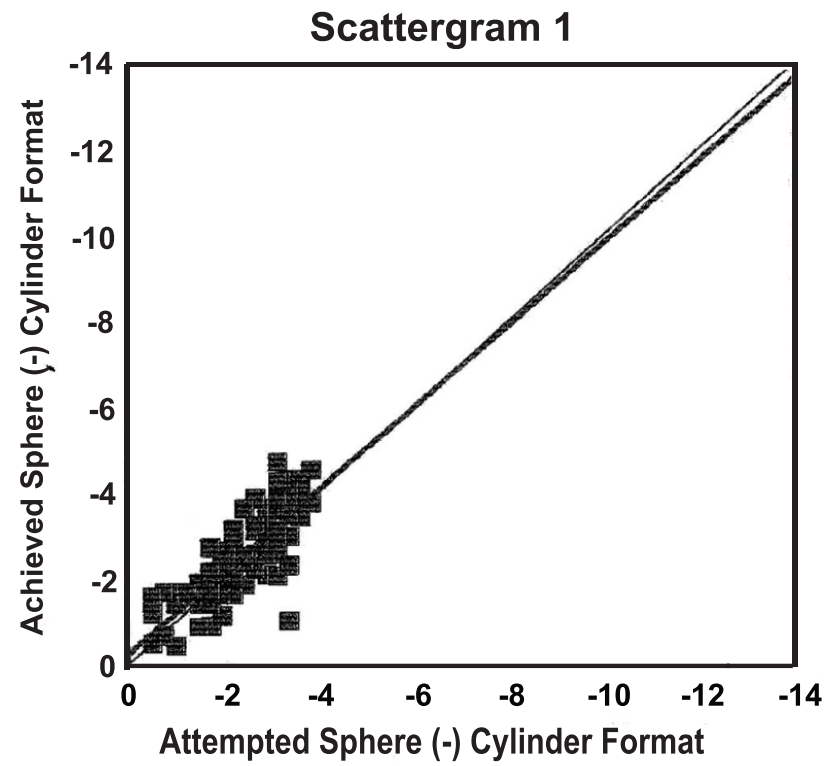

85 Eyes Presented

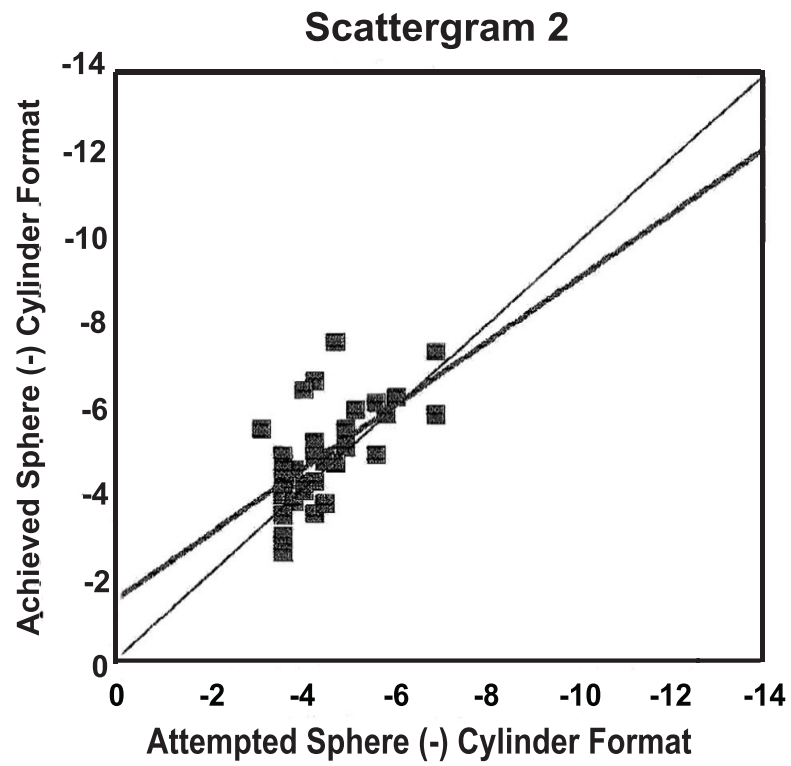

35 Eyes Presented

Figure 4 - Scattergram in groups 1 and 2 respectively, using the Refractive Surgery Consultant Elite database software ${ }^{\circledR}$ 
GROUP 1

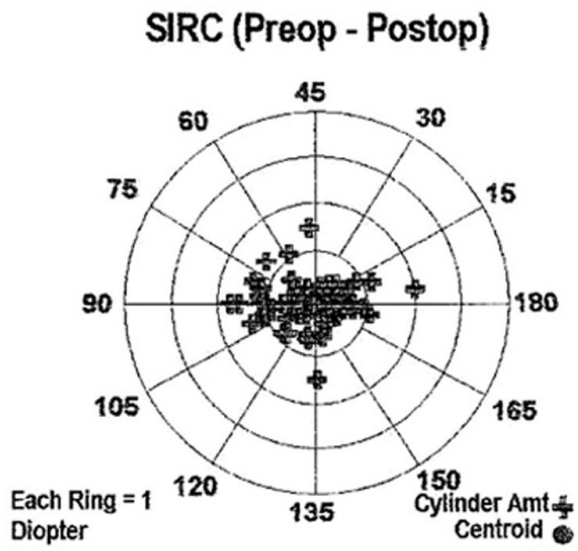

Centroid $=0.09$ D Axis 92 Degrees
GROUP 2

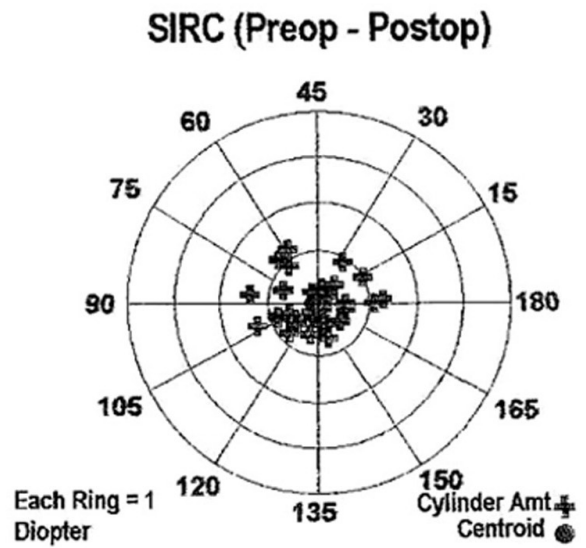

Centroid $=0.08 D$ Axis 89 Degrees

Each circle in a double angle plot represents one diopter. The cylinder axis is clearly marked. Each cross is the cylinder value for one eye and the dot is the "centroid" or distribution average. SIRC plot (preop - postop) or the achieved correction shows the cylinder changes affected by treatment.

Figure 5 - Surgical induced refractive change by Refractive Surgery Consultant Elite database software ${ }^{\circledR}$

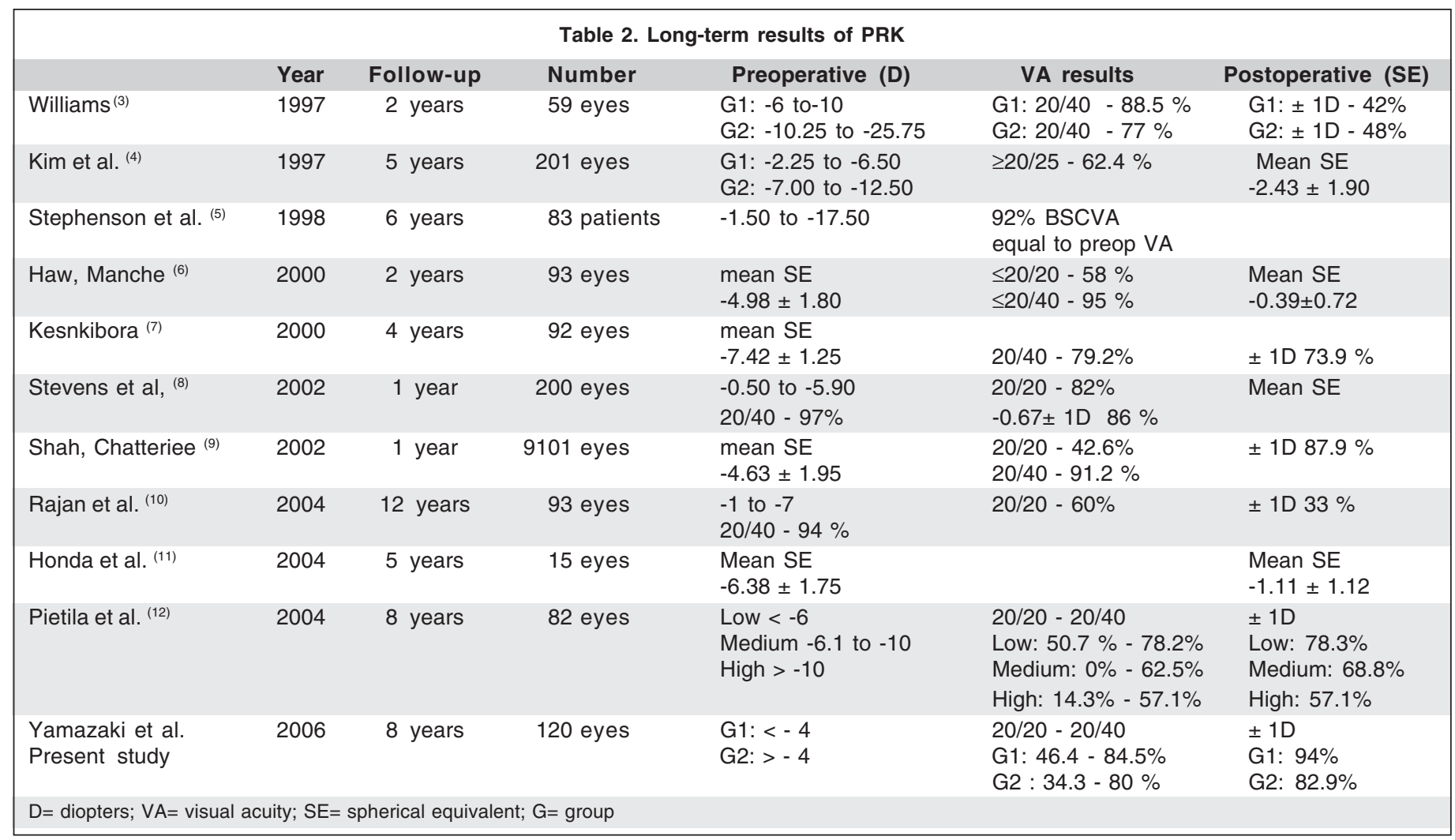

pain in the first 24 hours; a delay in the visual recovery lasting 3 to 5 days until epithelial healing; haze - a transient loss of corneal transparency, for a period of weeks to months after surgery ${ }^{(13-14)}$. The corneal healing response that manifes- ted as haze ${ }^{(15)}$ was reported particularly with higher amounts of myopia; therefore, this may be one of the reasons PRK has been used most often for lower amounts of myopia.

A study about the functional outcome and patient satis- 
faction after photorefractive keratectomy ${ }^{(16-17)}$, and on the overall satisfaction after PRK for low to severe myopia appears to be very appropriate. Night vision problems seem to constitute significant secondary effects that deserve further investigation.

\section{CONCLUSION}

Excimer laser PRK and PARK used in this study are effective and safe for low to moderate compound myopic astigmatism, and the accuracy and predictability compares favorably with other data in the peer-reviewed literature.

\section{RESUMO}

Objetivo: Relatar os resultados a longo prazo da cirurgia de ceratectomia fotorefrativa em miopia e astigmatismo miópico. Métodos: Estudo retrospectivo de120 olhos operados de ceratectomia fotorefrativa com um mínimo intervalo de 4 anos de seguimento pós-operatório (máximo de 96 meses e seguimento médio de 55 meses). Dividimos em grupo 1 (G1) com equivalente esférico (SE) até -4.00 dioptrias (D) e grupo 2(G2) SE >-4.00 D. O excimer laser Summit Apex Plus ${ }^{\circledR}$ foi usado na ablação. Foram obtidas acuidade visual não corrigida (UCVA) e melhor acuidade visual corrigida (BSCVA) e refração sob cicloplegia. Os dados foram analisados utilizando o programa Refractive Surgery Consultant Elite database ${ }^{\circledR}$. Resultados: G1 com 85 olhos (49 pacientes) apresentaram SE médio de $-2.42 \mathrm{D}$ e o G2 com 35 olhos (22 pacientes) e SE médio de -4,45 D. No G1 94\% e $82,9 \%$ no $\mathrm{G} 2$ estavam entre $\pm 1,00 \mathrm{D}$ de emetropia em 4 anos. A acuidade visual não corrigida foi de 20/30, ou melhor, em $82,0 \%$ nos olhos de G1 e 77,0\% de G2 no último seguimento. Nenhum paciente perdeu mais do que uma linha de visão no G2 comparado com 13,0\% em G1. Ganho de linha de visão após 4 anos foi respectivamente $11,9 \%$ em G1 e 2,9\% em G2. Correlação positiva estatisticamente significante foi encontrada entre correção refrativa programada versus atingida em ambos os grupos $(\mathrm{r}=0,925, \mathrm{p}<0,0005)$. Conclusão: Ceratectomia fotorefrativa foi um procedimento cirúrgico seguro e estável para corrigir erros refracionais miópicos, sem mudança significativa no equivalente esférico médio da refração pós-operatória em longo prazo.
Descritores: Ceratectomia fotorrefrativa por excimer laser; Miopia/cirurgia; Astigmatismo/cirurgia; Resultado de tratamento; Acuidade visual

\section{REFERENCES}

1. Gallinaro C, Toulemont PJ, Cochener B, Colin J. Excimer laser photorefractive keratectomy to correct astigmatism. J Caratact Refract Surg. 1996;22(5):557-63.

2. Carones F, Brancato R, Morico A, Venturini E, Gobbi PG. Compound myopic astigmatism correction using a mask in-the-rail excimer laser delivery system. Preliminary Results. Eur J Ophthalmol. 1996;6(3):221-33.

3. Williams DK. Multizone photorefractive keratectomy for high and very high myopia: long term results. J Cataract Refract Surg. 1997;23(7):1034-41. Comment in: J Cataract Refract Surg. 1997;23(7):969-70.

4. Kim JH, Kim MS, Hahn TW, Lee YC, Sah WJ, Park CK. Five years results of photorefractive keratectomy for myopia. J Cataract Refract Surg. 1997;23 (5):731-5. Comment in: J Cataract Refract Surg. 1997;23(5):689-91.

5. Stephenson CG, Gartry DS, O'Brart DP, Kerr-Muir MG, Marshall J. Photorefractive keratectomy. A 6-year follow-up study. Ophthalmology. 1998;105 (2):273-81.

6. Haw WW, Manche EE. One-year evaluation of myopic laser photoastigmatic refractive keratectomy using the Summit apex plus. phase III of a Food and Drug Administration clinical trial. Ophthalmology. 2000;107(8):1572-7

7. Keskinbora HK. Long-term results of multizone photorefractive keratectomy for myopia of $-6,0$ to $-10,0$ diopters. J Cataract Refract Surg. 2000;26(10): 1484-91.

8. Stevens J, Giubilei M, Ficker L, Rosen P. Prospective study of photorefractive keratectomy for myopia using the VISX StarsS2 excimer laser system. J Refract Surg. 2002;18(5):502-8.

9. Shah S, Chatterjee A, Smith RJ. Predictability and outcomes of photoastigmatic keratectomy using the Nidek EC-5000 excimer laser. J Cataract Refract Surg. 2002;28(4):682-8.

10. Rajan MS, Jaycock P, O'Brart D, Nystrom HH, Marshall J. A long-term study of photorefractive keratectomy: 12-year follow-up. Ophthalmology. 2004;111(10):1813-24. Comment in: Ophthalmology. 2004;111(10):1799-800.

11. Honda N, Hamada N, Amano S, Kaji Y, Hiraoka T, Oshika T. Five year follow-up of refractive keratectomy for myopia. J Refract Surg. 2004;20(2): 116-20

12. Pietila J, Makinen P, Pajari T, Suominen S, Keski-Nisula J, Sipila K, et al. Eight-year follow-up of photorefractive keratectomy for myopia. J Refract Surg. 2004;20(2):110-5.

13. Gartry DS, Kerr Muir MG, Marshall J. Photorefractive keratectomy with an argon fluoride excimer laser: a clinical study. Refract Corneal Surg. 1991; $7(6): 420-35$.

14. McDonald MB, Franzt JM, Klyce SD, Beuerman RW, Varnell R, Munnerlyn $\mathrm{CR}$, et al. Central photorefractive keratectomy for myopia. The blind eye study. Arch Ophthalmol. 1990;108(6):799-808.

15. Kuo IC, Lee SM, Hwang DG. Late-onset corneal haze and myopic regression after photorefractive keratectomy (PRK). Cornea. 2004;23(4):350-5.

16. Brunette I, Gresset J, Boivin JF, Pop M, Thompson P, Lafond GP, et al. Functional outcome and satisfaction after photorefractive keratectomy. Part 2: survey of 690 patients. Ophthalmology. 2000;107(9):1790-6.

17. Brunette I, Gresset J, Boivin JF, Boisjoly H, Makni H. Functional outcome and satisfaction after photorefractive keratectomy. Part 1: development and validation of a survey questionnaire. Ophthalmology. 2000;107(9):1783-9. 